\title{
Distribution and biological aspects of the introduced species Moina macrocopa (Straus, 1820) (Crustacea, Cladocera) in the semi-arid central region of Argentina
}

\author{
Alicia María Vignatti', Gabriela Cecilia Cabrera ${ }^{1} \&$ Santiago Andrés Echaniz ${ }^{1,2}$ \\ ${ }^{1}$ Facultad de Ciencias Exactas y Naturales, Universidad Nacional de La Pampa - UNLPam, Av. Uruguay, \\ 151, 6300, Santa Rosa, provincia de La Pampa, República Argentina. http://www.exactas.unlpam.edu.ar \\ ${ }^{2}$ Corresponding author: Santiago Andrés Echaniz, e-mail: sechaniz@cpenet.com.ar
}

VIGNATTI, A.M., CABRERA, G.C. \& ECHANIZ, S.A. Distribution and biological aspects of the introduced species Moina macrocopa (Straus, 1820) (Crustacea, Cladocera) in the semi-arid central region of Argentina. Biota Neotrop. 13(3): http://www.biotaneotropica.org.br/v13n3/en/abstract?article+bn01513032013

\begin{abstract}
Moina macrocopa is common in eutrophic water bodies. Two subspecies have been described: M. macrocopa macrocopa (Straus, 1820), whose original distribution was restricted to the Old World, and M. macrocopa americana Goulden, 1968, recorded only in North America. In 1994, the species was found in Bolivia, and in 1997 it was found in the northeast of Argentina. As the specimens belonged to M. macrocopa macrocopa in both cases, the authors suggested that it may have been introduced from the Old World by anthropogenic means. The aim of this study was to assess the distribution of M. macrocopa in La Pampa (Argentina), and provide information on its population characteristics under natural conditions. The species was recorded in six out of more than 100 water bodies surveyed; the specimens belong to M. macrocopa macrocopa. Although this species is not considered halophilic, the water bodies where it was found present high salinity (5.7 to $21.8 \mathrm{~g} . \mathrm{L}^{-1}$ ). All are shallow, temporary and hypertrophic due to the agricultural activities carried out in their basins. Densities were between 1 and 312.6 ind. $\mathrm{L}^{-1}$. Size varied between 0.6 and $1.8 \mathrm{~mm}$ and some specimens were larger than those of other places. The parthenogenetic fraction predominated and the number of eggs ranged between 2 and 23. No correlations were found between density, size, or number of eggs and the environmental parameters studied. The presence of M. macrocopa in Pampean lakes could be due to the introduction of fish from hatcheries in the province of Buenos Aires, where it is used as food. Considering that the invasive character of M. macrocopa has been recognized and that this study found that it is tolerant to a wide range of environmental conditions, attention should be paid to a possible displacement of its native congeneric species, typical of saline and temporary water bodies in central Argentina.
\end{abstract}

Keywords: Argentina, temporary lakes, Cladocera, Moina macrocopa, invasive species.

VIGNATTI, A.M., CABRERA, G.C. \& ECHANIZ, S.A. Distribución y aspectos biológicos de Moina macrocopa (Straus, 1820), (Crustacea, Cladocera) una especie introducida, en la región semiárida central de Argentina. Biota Neotrop. 13(3): http://www.biotaneotropica.org.br/v13n3/pt/abstract?article+bn01513032013

Resumen: Moina macrocopa es frecuente en cuerpos de agua eutróficos. Han sido descriptas dos subespecies, M. macrocopa macrocopa (Straus, 1820), cuya distribución original estaba restringida al Viejo Mundo y M. macrocopa americana Goulden, 1968, registrada en América del Norte. En 1994 fue hallada en Bolivia y en 1997 en el noreste de Argentina. Como en ambos casos los ejemplares pertenecían a la subespecie típica, los autores afirmaron que podría haber ocurrido una introducción antrópica desde el Viejo Mundo. El objetivo de esta contribución es dar a conocer la distribución de M. macrocopa en La Pampa (Argentina), y aportar información sobre características poblacionales en condiciones naturales. Se relevaron más de 100 cuerpos de agua y se registró esta especie en seis. Los ejemplares pertenecen a M. macrocopa macrocopa. Si bien no se la consideraba halófila, los lagos en los que se la halló presentaron salinidad elevada $\left(5,7\right.$ a 21,8 g. $\left.\mathrm{L}^{-1}\right)$. Todos fueron someros, temporarios e hipertróficos a causa de las actividades agropecuarias desarrolladas en sus cuencas. Se registraron densidades entre 1 y 312,6 ind.L ${ }^{-1}$. La talla varió entre 0,6 y 1,8 mm y algunos especímenes fueron más grandes que los de otros lugares. Predominó la fracción partenogenética y el número de huevos de las hembras osciló entre 2 y 23. No se encontraron correlaciones entre la densidad, talla o número de huevos y los parámetros ambientales. La presencia de $M$. macrocopa en lagunas pampeanas podría deberse a siembras de peces provenientes de criaderos de la provincia de Buenos Aires, donde es utilizada como alimento. Considerando que ha sido reconocido el carácter invasor de $M$. macrocopa y que en este estudio se comprobó su tolerancia, dado el amplio rango de condiciones ambientales en que se registró, debería prestarse atención a un posible desplazamiento de especies cogenéricas autóctonas, típicas de lagos salinos y temporarios del centro de Argentina.

Palabras clave: Argentina, lagos temporarios, Cladocera, Moina macrocopa, especie invasora. 


\section{Introduction}

Moina macrocopa is a cladoceran which has been mainly recorded in water bodies under heavy anthropogenic influence, such as sewage treatment basins, lakes for the paper-making industry sewage treatment, or rivers with strong domestic organic pollution (Espinosa-Chávez et al. 1992, Martínez \& Gutiérrez 1997, Benider et al. 1998, Vanjare et al. 2010). It is a species whose populations play an important role in food webs of epicontinental aquatic environments (Iannacone \& Alvariño 2000) and is of economic importance, since it is used in aquaculture as live food for larval stages of some fish. In a survey of freshwater cladocerans carried out in Perú, Valdivia-Villar (1988) reported the presence of $M$. macrocopa as a species introduced for use in aquaculture ventures. The species is also important because it is one of the most commonly used worldwide in standardized laboratory ecotoxicological bioassays (Martínez-Tabche et al. 2000, Iannacone \& Alvariño 2002, Nandini et al. 2004, Sarma et al. 2006, Mac-Quhae et al. 2007).

This cladoceran is characterized by having the head and caparace surface covered with long hairs, a broad, rounded head, without supraocular depression, anterior seta on the penultimate segment of the female's first trunk limb toothed, post-abdomen with seven to ten lateral feathered teeth and one short bifid tooth nearly equal in length, ephippium with two eggs and covered with polygonal cells (Paggi 1997, Elmoor-Loureiro et al. 2010). The male's first trunk limb has a large hook on the endopodite and long seta on the exopodite (Elmoor-Loureiro et al. 2010).

Two subspecies have been described so far: M. macrocopa macrocopa (Straus, 1820), the typical form, whose original distribution was restricted to water bodies of the Old World (Europe, Africa, Middle East and Asia), and M. macrocopa americana Goulden, 1968, recorded only in North America (Smirnov 1976).

Although the original distribution of $M$. macrocopa did not include South America, it was recorded in Bolivia more than two decades ago (Elias-Gutiérrez \& Zamuriano-Claros 1994) and some specimens were found in an ephemeral pond of Corrientes Province, Argentina, in 1994 (Paggi 1997). In both cases, the authors agreed that the specimens belonged to the typical subspecies, and thus claimed that its presence in these countries could be due to an anthropogenic introduction from the Old World.

The species was later recorded in the basin of the Rímac River, in Perú, although the authors did not mention the corresponding subspecies (Iannacone \& Dale 1999). The species was found again in Argentina, in Norris Lake, which is a natural water body in the province of Buenos Aires (Berasain et al. 2000), and in a small urban lake with high anthropogenic influence of the city of Santa Fe (Jose de Paggi et al. 2008). In 2008, M. macrocopa specimens were also recorded in the city of Rio de Janeiro (Brazil) (Elmoor-Loureiro et al. 2010).

In the province of La Pampa, in the semi-arid central region of Argentina, although more than 100 water bodies have been surveyed since 1992, M. macrocopa was first recorded in December 1999, in a sub-saline shallow temporary lake (Bajo de La Tigra) and subsequently in other five water bodies (Echaniz et al. 2005, 2006, Echaniz \& Vignatti 2011), being last recorded in February 2007. Although its presence was reported, no specific information was provided. Thus, the aim of this study was to assess the distribution of M. macrocopa in shallow lakes in the province of La Pampa, and to provide data on the population characteristics and lifecycle in natural conditions.

\section{Material and Methods}

\section{Study area}

Systematic sampling in more than 100 water bodies has been performed in the framework of research projects carried out at the Faculty of Exact and Natural Sciences of the University of $\mathrm{La}$ Pampa (La Pampa, Argentina) since 1992, with an aim of obtaining data regarding the ecology and distribution of zooplankton in lakes and reservoirs in the province of La Pampa. In the present work, we analyzed qualitative and quantitative samples of six water bodies in which this species had been recorded. These lakes are all shallow, with depths between $0.17 \mathrm{~m}$ and $1.96 \mathrm{~m}$ (Figure 1). All are temporary, fed by rainfall and to a lesser extent by groundwater inputs. They are located in a region where evapotranspiration exceeds precipitation (Ponce de León 1998), which is a situation that leads to marked changes in salinity. All of the water bodies are located in arheic basins where agriculture with the addition of fertilizers and extensive or semi-intensive cattle breeding is carried out (Echaniz 2010, Echaniz et al. 2010, Vignatti 2011). Aquatic macrophytes and fish fauna are lacking in all lakes.

\section{Field and laboratory work}

Qualitative samples were collected using tows with networks of 40 micrometers of mesh opening, whereas quantitative samples were collected with a Schindler-Patalas trap of 10 liters, fitted with a network of the same mesh opening. In the Bajo de La Tigra, only one qualitative sample of zooplankton was obtained, whereas in the other lakes, samplings were carried out on a monthly basis in different periods (Table 1).

Samples were anesthetized in the field with $\mathrm{CO}_{2}$ until their analysis in the laboratory and subsequently fixed with formalin to $5-8 \%$. The material was deposited in the plankton library of the Faculty of Exact and Natural Sciences of the National University of La Pampa (La Pampa, Argentina).

The following parameters were measured in situ: water transparency (Secchi disk $22 \mathrm{~cm}$ in diameter), $\mathrm{pH}$ (digital $\mathrm{pH}$ meter Corning PS-15), and concentration of dissolved oxygen (DO) and water temperature (Oximeter Lutron DO 5510). Water samples to determine salinity were taken using the method of solid residue (American... 1992). Total concentrations of nutrients

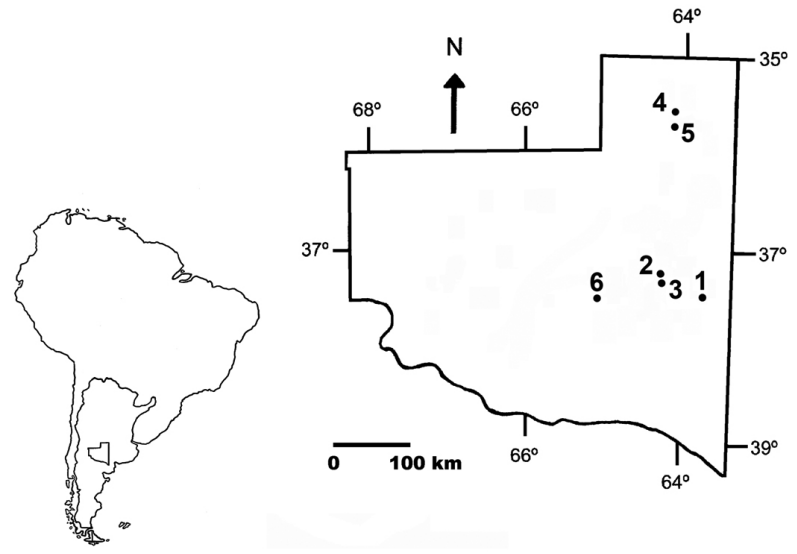

Figure 1. Distribution of Moina macrocopa macrocopa in La Pampa province: 1: Bajo de La Tigra ( $37^{\circ} 26^{\prime} \mathrm{S}$ and $\left.63^{\circ} 38^{\prime} \mathrm{W}\right)$; 2 : El Destino (37 $07^{\circ} \mathrm{S}$ and $\left.64^{\circ} 17^{\prime} \mathrm{W}\right)$; 3 : La Laura ( $37^{\circ} 10^{\prime} \mathrm{S}$ and $\left.64^{\circ} 17^{\prime} \mathrm{W}\right)$; 4 : Pey - Ma (35 $26^{\circ} \mathrm{S}$ and $\left.64^{\circ} 15^{\prime} \mathrm{W}\right) ; 5$ : Aime $\left(35^{\circ} 28^{\prime} \mathrm{S}\right.$ and $\left.64^{\circ} 15^{\prime} \mathrm{W}\right)$ y 6 : El Carancho $\left(37^{\circ}\right.$ $27^{\prime} \mathrm{S}$ and $\left.65^{\circ} 04^{\prime} \mathrm{W}\right)$. 
Vignatti, A.M. et al.

Table 1. Main physicochemical parameters of the environments where Moina macrocopa macrocopa was recorded. Pey-Ma and Aime, where Moina macrocopa macrocopa was found on more than two sampling occasions. Mean values are indicated and minima and maxima are between parentheses. w/d: without data.

\begin{tabular}{|c|c|c|c|c|c|c|}
\hline & La Tigra & El Destino & La Laura & Pey-Мa & Aime & El Carancho \\
\hline Years & 1999 & 2001 & 2001 & $2005-2006$ & 2006 & 2007 \\
\hline Months & Dec. & Jan. & Nov. & Dec.-Jan.-Feb.-Mar. & Apr.-May-June & Feb. \\
\hline Depht max. (m) & 0.80 & 1.25 & 1.96 & $\begin{array}{c}1.46 \\
(1.4-1.5)\end{array}$ & $\begin{array}{c}0.23 \\
(0.17-0.29)\end{array}$ & 1.60 \\
\hline Water temp. $\left({ }^{\circ} \mathrm{C}\right)$ & 24.00 & 22.83 & 19.83 & $\begin{array}{c}23.4 \\
(20.8-26.9)\end{array}$ & $\begin{array}{c}13.6 \\
(9.4-19.1)\end{array}$ & 19.60 \\
\hline Salinity $\left(\mathrm{g} . \mathrm{L}^{-1}\right)$ & 15.10 & 18.51 & 12.79 & $\begin{array}{c}20.64 \\
(18.4-21.8)\end{array}$ & $\begin{array}{c}11.94 \\
(9.7-14.2)\end{array}$ & 5.70 \\
\hline pH & 8.40 & 9.20 & 9.50 & $\begin{array}{c}9 \\
(8.8-9.3)\end{array}$ & $\begin{array}{c}9.2 \\
(8.9-9.3)\end{array}$ & 9.20 \\
\hline Transparency (m) & 0.15 & 0.28 & 1.96 & $\begin{array}{c}0.21 \\
(0.15-0.31)\end{array}$ & $\begin{array}{c}0.04 \\
(0.02-0.06)\end{array}$ & 0.68 \\
\hline Chl. $a\left(\mathrm{mg} \cdot \mathrm{m}^{-3}\right)$ & $\mathrm{w} / \mathrm{d}$ & $\mathrm{s} / \mathrm{d}$ & $\mathrm{s} / \mathrm{d}$ & $\begin{array}{c}61.5 \\
(35.2-94.8)\end{array}$ & $\begin{array}{c}181.2 \\
(126.8-244.1)\end{array}$ & 3.58 \\
\hline TP $\left(\mathrm{mg} . \mathrm{L}^{-1}\right)$ & $\mathrm{w} / \mathrm{d}$ & $\mathrm{w} / \mathrm{d}$ & $\mathrm{w} / \mathrm{d}$ & $\begin{array}{c}13.1 \\
(11.2-15)\end{array}$ & $\begin{array}{c}20.7 \\
(13.7-25.8)\end{array}$ & 7.50 \\
\hline TN $\left(\mathbf{m g} . \mathbf{L}^{-1}\right)$ & $\mathrm{w} / \mathrm{d}$ & $\mathrm{w} / \mathrm{d}$ & w/d & $\begin{array}{c}26.7 \\
(20.6-31.9)\end{array}$ & $\begin{array}{c}32.5 \\
(26.3-39.49)\end{array}$ & 5.63 \\
\hline DO $\left(m g . L^{-1}\right)$ & $\mathrm{w} / \mathrm{d}$ & $\mathrm{w} / \mathrm{d}$ & $\mathrm{w} / \mathrm{d}$ & $\begin{array}{c}5,4 \\
(3.1-9.8)\end{array}$ & $\begin{array}{c}10.1 \\
(7.5-13.6)\end{array}$ & 8.70 \\
\hline TSS (mg.L. $\left.\mathbf{L}^{-1}\right)$ & $\mathrm{w} / \mathrm{d}$ & $\mathrm{w} / \mathrm{d}$ & $\mathrm{w} / \mathrm{d}$ & $\begin{array}{c}74.9 \\
(54.7-93)\end{array}$ & $\begin{array}{c}465,1 \\
(207.9-831.4)\end{array}$ & 7.38 \\
\hline ISS (mg. $\left.\mathbf{L}^{-1}\right)$ & $\mathrm{w} / \mathrm{d}$ & $\mathrm{w} / \mathrm{d}$ & $\mathrm{w} / \mathrm{d}$ & $\begin{array}{c}19.9 \\
(10-39.2)\end{array}$ & $\begin{array}{c}324.2 \\
(116.4-614.3)\end{array}$ & 3.36 \\
\hline OSS (mg.L L $\left.{ }^{-1}\right)$ & $\mathrm{w} / \mathrm{d}$ & $\mathrm{w} / \mathrm{d}$ & $\mathrm{w} / \mathrm{d}$ & $\begin{array}{c}55 \\
(38,7-78.7)\end{array}$ & $\begin{array}{c}140.8 \\
(91,4-217.1)\end{array}$ & 4.02 \\
\hline
\end{tabular}

(phosphorus - TP and nitrogen - NT), total suspended solids (TSS), organic suspended solids (OSS), inorganic suspended solids (ISS) and chlorophyll $a(\mathrm{Chl} . a)$ were determined in three of the six lakes (American... 1992, Arar 1997).

The reports of Goulden (1968), Smirnov (1976), Paggi (1997) and Elmoor-Loureiro et al. (2010) were used for the taxonomic determination of species and subspecies. Counts of the quantitative samples were conducted in Bogorov chambers of $5 \mathrm{ml}$, under a stereoscopic microscope (with the exception of the samples from Bajo de La Tigra); the number of eggs per female and the spectrum of sizes were determined with a conventional optical microscope equipped with a micrometer eyepiece (Carl Zeiss). In all cases, a minimum of 30 specimens were measured, and in cases when fewer were recorded, all were measured.

A nonparametric Kruskal-Wallis test was applied to determine significant differences between biological parameters and Spearman correlation coefficients were calculated (Sokal \& Rohlf 1995, Zar 1996, Pereyra et al. 2004) to examine relationships between environmental factors and zooplankton attributes. Infostat (Di Rienzo et al. 2010) and Past (Hammer et al. 2001) software were used for all the analyses.

\section{Results}

The setae of the ventral edge of the shells of the specimens collected in all the lakes were not grouped and were roughly the same size (Figure 2). The number of setae of the ventral edge of the shells ranged from 42 to 74 and was different among lakes $(\mathrm{H}=33.1 ; \mathrm{p}=0.0000)$ (Figure 3$)$. The samples from El Destino (49.2 \pm 3.6$)$ and Pey-Ma $(47.7 \pm 4.2)$ presented the lowest quantities and variations, whereas those from Bajo de la Tigra presented the
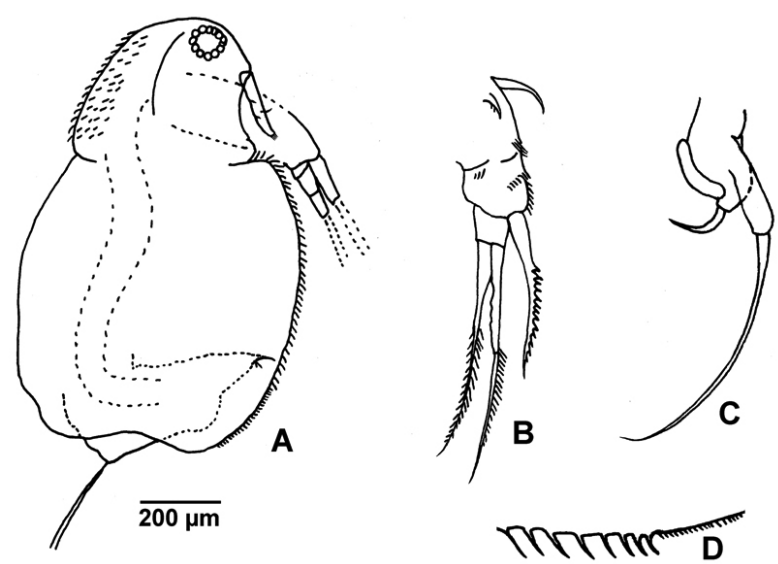

Figure 2. Moina macrocopa macrocopa. A: Parthenogenetic female (lateral view). B: First trunk limb of female. C: First trunk limb of male. D: Ventral rims of the shells.

largest (61.2 \pm 9.2$)$ (Figure 3). The ephippium surface was covered by relatively polygonal cells that protruded from the surface.

In the Bajo de La Tigra, M. macrocopa was recorded on the only occasion in which the lake was sampled, in Pey-Ma it was found along four consecutive months, in Aime along three consecutive months, and in the other three lakes it was found only in one occasion (Table 1).

The salinity of the water bodies where specimens were found was relatively high, ranging from 5.7 g.L $\mathrm{L}^{-1}$ to 21.8 g.L $\mathrm{L}^{-1}$ (Table 1). The water temperature varied between 9.4 and $26.9^{\circ} \mathrm{C}$ and $\mathrm{pH}$ 
values were always high, ranging between 8.4 and 9.5 (Table 1). Water transparency also presented a wide range of variation, and was very low in Aime $(0.02 \mathrm{~m})$ and very high in La Laura $(1.96 \mathrm{~m})$ (Table 1).

The overall mean density of the population was higher in the lakes where the species was recorded in more than one occasion: 84 ind. $\mathrm{L}^{-1}( \pm 152.6)$ in Pey-Ma and 49.3 ind. $\mathrm{L}^{-1}( \pm 30.5)$ in Aime. In Pey-Ma, density was low in the first few months (19, 3 and 1 ind. $L^{-1}$ in December, January and February, respectively) and then reached a high maximum density in March (312.6 ind. $\mathrm{L}^{-1}$ ). In Aime, the species was present in April, May and June, with total densities of 16, 60 and 56 ind. $\mathrm{L}^{-1}$, respectively. In the lakes where the species was found in a single occasion, the density was higher in El Carancho (51.7 ind. $\mathrm{L}^{-1}$ ) followed by El Destino (22.9 ind. $\mathrm{L}^{-1}$ ) and La Laura (9.8 ind. $\left.\mathrm{L}^{-1}\right)$. No correlations were found between the density of populations and the environmental parameters studied.

In all cases, the parthenogenetic fraction of the population predominated over the gamogenetic one. In Bajo de La Tigra, the parthenogenetic fraction represented $100 \%$ of the population. In the other lakes, the parthenogenetic females accounted for $99 \%(\mathrm{La}$ Laura), 96\% (Pey-Ma), 89\% (Aime), 87\% (El Destino) and 70\% (El Carancho) of the population, respectively (Figure 4).

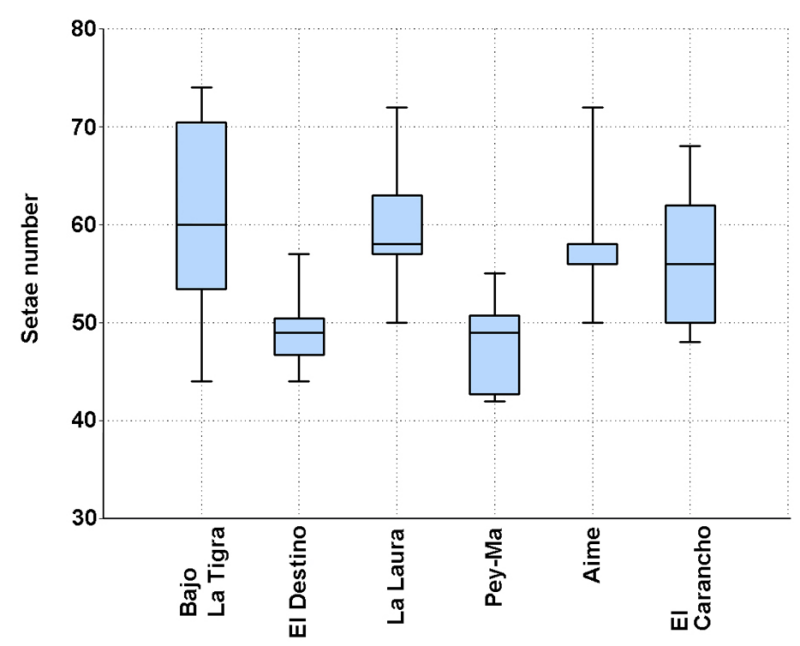

Figure 3. Number of setae of de ventral rims of the shells.
The sizes of the specimens varied between 0.6 and $1.8 \mathrm{~mm}$ and were different among the lakes studied $(\mathrm{H}=118.8 ; \mathrm{p}=0.0000)$. The largest specimens were recorded in El Carancho (Table 2). When considering the parthenogenetic females with eggs, the lengths were also different $(\mathrm{H}=112.7 ; \mathrm{p}=0.0000)$; the largest specimens were measured in El Carancho and Pey-Ma, where they were close to 1.8 and $1.4 \mathrm{~mm}$, respectively (Table 2). The sizes of the gamogenetic females were also different $(H=17.58 ; \mathrm{p}=0.0005)$, with the largest ones recorded in El Carancho, where some specimens were longer than $1.6 \mathrm{~mm}$ (Table 2). The size of the males also differed $(\mathrm{H}=11.68$; $\mathrm{p}=0.0199)$ and the largest specimens, which reached $0.9 \mathrm{~mm}$, were found in La Laura and El Carancho. No correlations were found between total sizes or the different fractions and the environmental parameters studied.

The mean number of eggs per parthenogenetic female was very variable and differed between lakes $(H=79.25 ; \mathrm{p}=0.0000)$, being higher in the specimens from Bajo de La Tigra (12.8) followed by those from La Laura (10.3). Although the parthenogenetic females of Pey-Ma had a lower mean number of eggs, they were the females with greatest variation, since they presented between 3 and 23 eggs (Figure 5). No correlations were found between the number of eggs and the size of parthenogenetic females or the environmental parameters studied.

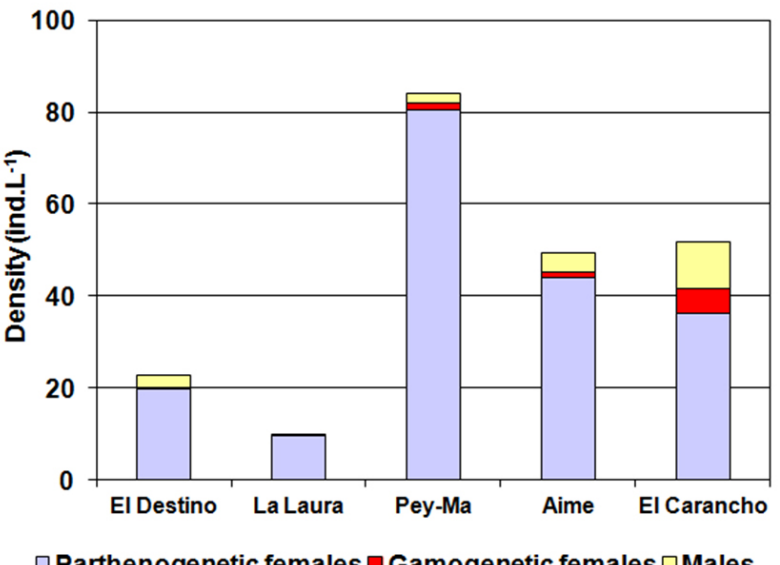

Figure 4. Total density of $M$. macrocopa macrocopa (in ind. $\mathrm{L}^{-1}$ ). Parthenogenetic fraction (blue). Gamogenetic fraction: ephippial females (red) and males (green).

Table 2. Sizes (mean, minimum and maximum values) of Moina macrocopa macrocopa $(\mathrm{mm})$, both of the general population and of the parthenogenetic and gamogenetic fractions (females and males) in particular.

\begin{tabular}{|c|c|c|c|c|c|}
\hline & & $\begin{array}{c}\text { Population } \\
\text { general sizes }\end{array}$ & $\begin{array}{c}\text { Parthenogenetic } \\
\text { females (with eggs) }\end{array}$ & $\begin{array}{c}\text { Gamogenetic } \\
\text { females }\end{array}$ & Males \\
\hline La Tigra & $\begin{array}{l}\text { Mean } \\
\text { Min.-max. }\end{array}$ & $\begin{array}{c}\mathbf{1 . 0 8} \\
(0.78-1.38)\end{array}$ & $\begin{array}{c}\mathbf{1 . 0 7} \\
(0.78-1.38)\end{array}$ & & \\
\hline El Destino & $\begin{array}{l}\text { Mean } \\
\text { Min.-max. }\end{array}$ & $\begin{array}{c}\mathbf{0 . 9 3} \\
(0.69-1.29)\end{array}$ & $\begin{array}{c}\mathbf{0 . 9 4 0} \\
(0.69-1.19)\end{array}$ & $\begin{array}{c}\mathbf{0 . 7 9} \\
(0.76-0.83)\end{array}$ & $\begin{array}{c}\mathbf{0 . 6 9 9} \\
(0.69-0.71)\end{array}$ \\
\hline La Laura & $\begin{array}{l}\text { Mean } \\
\text { Min.-max. }\end{array}$ & $\begin{array}{c}\mathbf{0 . 9 0 0} \\
(0.71-1.19)\end{array}$ & $\begin{array}{c}\mathbf{0 . 9 0 5} \\
(0.71-1.19)\end{array}$ & & $\begin{array}{c}\mathbf{0 . 8 4 0} \\
(0.78-0.91)\end{array}$ \\
\hline Pey-Ma & $\begin{array}{l}\text { Mean } \\
\text { Min.-max. }\end{array}$ & $\begin{array}{c}\mathbf{0 . 9 5 4} \\
(0.66-1.39)\end{array}$ & $\begin{array}{c}\mathbf{1 . 0 0 5} \\
(0.71-1.39)\end{array}$ & $\begin{array}{c}\mathbf{0 . 7 6} \\
(0.70-0.80)\end{array}$ & 0.66 \\
\hline Aime & $\begin{array}{l}\text { Mean } \\
\text { Min.-max. }\end{array}$ & $\begin{array}{c}\mathbf{1 . 0 0 2} \\
(0.64-1.31)\end{array}$ & $\begin{array}{c}\mathbf{1 . 2 8 1} \\
(1.23-1.31)\end{array}$ & $\begin{array}{c}\mathbf{1 . 1 8} \\
(1.14-1.24)\end{array}$ & $\begin{array}{c}\mathbf{0 . 7 1} \\
(0.64-0.80)\end{array}$ \\
\hline El Carancho & $\begin{array}{l}\text { Mean } \\
\text { Min.-max. }\end{array}$ & $\begin{array}{c}\mathbf{1 . 3 6 3} \\
(0.86-1.78)\end{array}$ & $\begin{array}{c}\mathbf{1 . 4 3 2} \\
(1.00-1.78)\end{array}$ & $\begin{array}{c}\mathbf{1 . 3 6} \\
(1.00-1.63)\end{array}$ & $\begin{array}{c}\mathbf{0 . 8 8 6} \\
(0.86-0.91)\end{array}$ \\
\hline
\end{tabular}




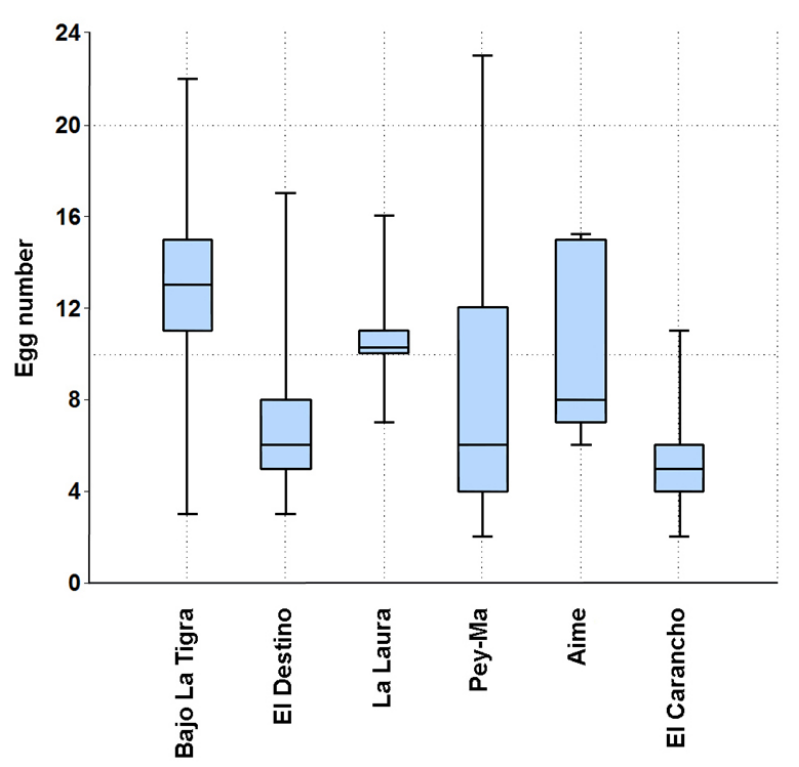

Figure 5. Parthenogenetic females: Number of eggs.

\section{Discussion}

The analysis of the relevant characters to distinguish the two subspecies allows the assertion that the specimens found in $\mathrm{La}$ Pampa belong to M. macrocopa macrocopa, which is native to the Old World. Both the distribution pattern of the row of setae of the ventral edge of the shells (not grouped and approximately of the same size) and the ornamentation of the ephippium surface (covered by polygonal cells that protrude from the surface) are similar to those of the specimens recorded in Corrientes (Paggi 1997). The row of ventral filaments is also similar to that of the specimens found in Rio de Janeiro (Elmoor-Loureiro et al. 2010), whereas the ephippium surface seems to be different; the ephippium surface of the specimens of Rio de Janeiro seems to be more similar to that of the subspecies M. macrocopa americana, while the ephippium surface of the specimens of La Pampa is similar to that of the specimens of the Old World. One difference between the specimens of La Pampa and those from Corrientes and Rio de Janeiro is the smaller number of filaments of the ventral edge of the shells and their greater variability, since those from Corrientes and Rio de Janeiro showed between 73 and 76 filaments; this makes the Pampean specimens more similar to those found in Bolivia by Elias-Gutiérrez \& Zamuriano-Claros in 1994.

Although it has been shown that M. macrocopa can survive up to $35{ }^{\circ} \mathrm{C}$ under controlled laboratory conditions (Benider et al. 2002), this species has been recorded in natural conditions in temperatures ranging between 8 and $26^{\circ} \mathrm{C}$ (Benider et al. 2002). The temperature range in the lakes of the province of La Pampa is similar, although the highest temperature at which $M$. macrocopa was recorded was slightly higher (almost $27^{\circ} \mathrm{C}$ ). The greatest fertility was observed with high water temperatures, with the highest mean number of eggs per female verified in Bajo de La Tigra at $24{ }^{\circ} \mathrm{C}$. Although no correlation was found, the maximum density was recorded at the end of the summer in Pey-Ma, when a large predominance of the parthenogenetic fraction was found. This allows this species to be characterized as widely tolerant, but with a certain preference for higher temperatures, which is similar to that recorded for its congeneric Moina eugeniae Olivier 1954 in lakes of La Pampa (Vignatti et al. 2012).

Moina macrocopa has not been categorized as a halophilic species. By means of laboratory bioassays, Suhett et al. (2011) found that the tolerance to salinity stress was associated with the presence of humic substances in the water, but considered a maximum value of 5.5 g.L.- . According to Löffler (1961), this species may inhabit environments with levels of up to 22.2 g.L. ${ }^{-1}$, whereas Alonso (1996) mentioned that the waters inhabited by M. macrocopa in Spain are temporary and not very saline. However, in La Pampa, this species has been recorded in water bodies with a wide range of salinity of up to approximately 22 g.L.-1 (Hammer 1986).

Anthropic eutrophication, which is due to the input of an excess of nutrients (phosphorus and nitrogen) into any water body, can come from three sources: industrial, domestic or agricultural (Freitas \& Rocha 2011). In other parts of the world, M. macrocopa is often associated with hypertrophic or eutrophic environments with high anthropogenic influence, especially those under the influence of cities; for example, sewage treatment basins or rivers with strong domestic organic pollution, such as the Mula River in India (Vanjare et al. 2010), or those impacted by industrial activities, such as lakes for paper-making industry sewage treatment (Espinosa-Chávez et al. 1992, Martínez \& Gutiérrez 1997, Benider et al. 1998, 2002). In all cases, the constant discharge of wastewater increases their organic load, usually resulting in pollution (Loh et al. 2009).

In the case of Pampean aquatic environments where $M$. macrocopa was recorded, the trophic state was very high, but the most important anthropogenic influence is caused by agricultural activities. These activities are reflected in the high content of nutrients contributed by the fertilization of crops as well as by the feces and urine of cattle raised in the surrounding area. This is enhanced by the arheic character of the basins, which favors the concentration of nutrients both in water and in sediment (Echaniz et al. 2009, 2010, 2012, Echaniz \& Vignatti 2011).

Goulden (1968) reported a maximum size of $1.5 \mathrm{~mm}$ for parthenogenetic females, but some specimens of the Pampean lakes, as well as some from Corrientes (Paggi 1997) and Rio de Janeiro, exceed this size (Elmoor-Loureiro et al. 2010) (1.19 mm and $1.08 \mathrm{~mm}$, respectively). The sizes of the specimens from La Pampa were similar to those recorded by Hanazato \& Yasuno (1984) and Benider et al. (2002), although in the latter two cases they were specimens bred in the laboratory, under controlled feeding and temperatures between 20 and $25^{\circ} \mathrm{C}$.

The populations of M. macrocopa recorded in Pampean lakes could have originated from the introduction of larvae of Odontesthes bonariensis (Cuvier \& Valenciennes 1835) from hatcheries of the Buenos Aires province. This introduction may have occurred in several water bodies, some of which were relatively close to the lakes in which the species was recorded (Del Ponti pers. comm.).

Paggi (1997) reported that specimens of M. macrocopa imported from Japan were raised in laboratories of that province as live food for silverside juveniles. Considering that juveniles are transported in plastic bags containing water from the breeding site, some living specimens or their structures of resistance (ephippia) could have been transported involuntarily. It must also be considered that their presence in La Pampa could be due to natural dispersal, as is the case of other species of cladocerans in other parts of the world (Elias-Gutiérrez 1995), since it is known that wind, water and biotic means (e.g. birds) are used for dispersal (Badii \& Landeros 2006-2007). This could have occurred either from water bodies of La Pampa in which fish larvae were introduced or from outside the provincial territory, since M. macrocopa was also recorded in Norris Lake (Berasain et al. 2000), which is a natural water body in the province of Buenos Aires.

Some authors consider the invasion of non-native species as the second threat to global biodiversity (after the loss and fragmentation of habitat) (Walker \& Steffen 1997), whereas others consider it the 
first (Unión... 1999). Badii \& Landeros (2006-2007) mentioned that invasive species could thrive and transform a new habitat, having the potential to displace native species until they are on the edge of extinction (Comisión... 2001). According to the National Advisory Committee on Invasive Species of Mexico (2010), 40\% of extinctions in continental aquatic environments are due to predation, parasitism, or competition with invasive species. Ricciardi \& Rasmussen (1999) indicated that the rates of extinction in aquatic environments, especially those of epicontinental waters, are five times higher than those on the continent.

The invasive nature of M. macrocopa has been reported by several authors. Okolodkov et al. (2007) included this species within a list of 94 potential invaders of inland waters, coastal and littoral lakes in Mexico, suggesting more than one possible mechanism for their introduction, among which they considered aquaculture activities. Badii \& Landeros (2006-2007) noted that a successful colonizing species presented type $r$ strategies characterized by a short generation time and high fertility, which are characteristics that have also been observed in M. macrocopa (Benider et al. 2002). Allendorf \& Lundquist (2003) mentioned that the success of invasive species could also be due to the absence of enemies, which would enable them to grow and reproduce without the regulatory effect of a predator on the population. As mentioned previously, since the water bodies of $\mathrm{La}$ Pampa where $M$. macrocopa was found have no fish or invertebrate predators, the "top-down" regulatory factor should be ruled out.

The environmental parameters in the six lakes studied ranged widely, indicating that this species is relatively tolerant, which would confirm their opportunistic nature and potentially invasive nature. Based on this information, special attention should be paid to M. macrocopa, a potentially invasive species that could displace other congeneric native species such as $M$. eugeniae, which is common in saline and temporary lakes in the province of La Pampa, including the environments where M. macrocopa was found.

\section{Acknowledgements}

We thank the Facultad de Ciencias Exactas y Naturales de la Universidad Nacional de La Pampa for financial support and two anonymous reviewers whose work improved this contribution.

\section{References}

ALLENDORF, F.W. \& LUNDQUIST, L.L. 2003. Population Biology, evolution, and control of invasive species. Conserv. Biol. 17(1):24-30. http://dx.doi.org/10.1046/j.1523-1739.2003.02365.x

ALONSO, M. 1996. Crustacea, Branquiopoda. In Fauna Ibérica. vol. 7 (M.A. Ramos, J. Alba-Tercedor, X. Belléz, J. Gosálbez, A. Guerra, E. Macpherson, J. Serrano \& J. Templado, eds.). Museo Nacional de Ciencias Naturales, CSIC, Madrid, 486p.

AMERICAN PUBLIC HEALTH ASSOCIATION - APHA. 1992. Standard Methods for the Examination of Water and Wastewater. 18th edition. APHA, AWWA, WPCF, Washington.

ARAR, E.J. 1997. In Vitro Determination of Chlorophylls a, b, c + c and Pheopigments in Marine and Freshwater Algae by Visible Spectrophotometry. Method 446.0. U.S. Environmental Protection Agency.

BADII, M.H. \& LANDEROS, J. 2006-2007. Invasión de especies o el tercer jinete de apocalipsis ambiental, una amenaza a la sustentabilidad (Invasive species or the third horseman of environmental apocalypses, a threat to sustainability). Int. J. Good Conscie. 2(1):39-53. www.daenajournal.org.

BENIDER, A., TIFNOUTI, A. \& POURRIOT, R. 1998. Growth of Moina macrocopa (Straus 1820) (Crustacea: Cladocera). Influence des conditions trophiques, de la densité de population, du groupement et de la température. Annls. Limnol. 34(4):387-399. http://dx.doi.org/10.1051/ $\operatorname{limn} / 1998031$
BENIDER, A., TIFNOUTI, A. \& POURRIOT, R. 2002. Reproduction parthénogénétique de Moina macrocopa (Straus 1820) (Crustacea: Cladocera). Influence of trophic conditions, population density and temperatura. Hydrobiologia 468:1-11. http://dx.doi. org/10.1023/A:1015214530485

BERASAIN, G., REMES LENICOV, M. \& COLAUTI, D. 2000. Los Tamariscos, La Manga y de Norris. Lagunas del partido de Coronel Dorrego. Campaña de relevamientos limnológicos e ictiológicos. Dirección provincial de fomento, producción y desarrollo de la pesca, Subsecretaría de actividades pesqueras, Ministerio de Producción, Pcia de Bs. As., 20p.

COMISIÓN PARA LA COOPERACIÓN AMBIENTAL DE NORTEAMÉRICA - CCA. 2001. Prevención de la Introducción y Propagación de Especies Invasoras Acuáticas en América del Norte: Actividades del Taller. 81p.

DI RIENZO, J.A., CASANOVES, F., BALZARINI, M.G., GONZÁLEZ, L., TABLADA, M. \& ROBLEDO, C.W. 2010. InfoStat (versión 2010). Grupo InfoStat, FCA, Universidad Nacional de Córdoba, Argentina. http://www.infostat.com.ar/. (último acesso em 20/04/2011).

ECHANIZ, S.A. 2010. Composición y abundancia del zooplancton en lagunas de diferente composición iónica de la provincia de La Pampa. Tesis Doctoral, Universidad Nacional de Río Cuarto, Facultad de Ciencias Físico Químicas y Naturales.

ECHANIZ, S., VIGNATTI, A., PAGGI, J.C. \& JOSE DE PAGGI, S. 2005. Riqueza y composición del zooplancton de lagunas saladas de Argentina. Rev. FABICIB 9:25-39.

ECHANIZ, S.A., VIGNATTI, A.M., JOSE DE PAGGI, S., PAGGI, J.C. \& PILATI, A. 2006. Zooplankton seasonal abundance of South American saline shallow lakes. Int. Rev. Hydrobiol. 91(1):86-100. http://dx.doi. org/10.1002/iroh.200510803

ECHANIZ, S., VIGNATTI, A. \& CABRERA, G. 2009. Características limnológicas de una laguna turbia orgánica de la provincia de La Pampa y variación estacional del zooplancton. Biol. Acuat. 26:71-82.

ECHANiZ, S., VIGNATTI, A.M., JOSE DE PAGGI, S.B. \& PAGGI, J.C. 2010. Los nutrientes en los sedimentos de lagunas de La Pampa. Relación con la granulometría y uso de la tierra. In Libro de Trabajos del $3^{\circ}$ Congreso Pampeano del Agua. p.23-31.

ECHANIZ, S.A. \& VIGNATTI, A.M. 2011. Seasonal variation and influence of turbidity and salinity on the zooplankton of a saline lake in central Argentina. Lat. Am. J. Aquat. Res. 39(2):306-315. http://dx.doi. org/10.3856/vol39-issue2-fulltext-12

ECHANIZ, S.A., VIGNATTI, A.M., CABRERA, G.C. \& JOSE DE PAGGI, S.B. 2012 Zooplankton richness, abundance and biomass of two hypertrophic shallow lakes with different salinity. Biota Neotrop. 12(2): 37-44. http:/www.biotaneotropica.org.br/v12n2/en/ abstract?article+bn00712022012 (último acesso em 06/03/2013).

ELIAS-GUTIÉRREZ, M. 1995. Notas sobre los cladóceros de embalses a gran altitud en el Estado de México, México. An. Esc. Nac. Cienc. Biol. 40:197-214.

ELIAS-GUTIÉRREZ, M. \& ZAMURIANO-CLAROS, R. 1994. Primer registro de Moina macrocopa (Daphniiformes: Moinidae) en Bolivia. Rev. Biol. Trop. 42(1-2):385.

ELMOOR-LOUREIRO, L.M.A., SANTÁNGELO, J.M., LOPES P.M. \& BOZELLI, R.L. 2010. A new report of Moina macrocopa (Straus, 1820) (Cladocera Anomopoda) in South America. Braz. J. Biol. 70(1):225-226. http://dx.doi.org/10.1590/S1519-69842010000100031

ESPINOSA-CHÁVEZ, F., MARTÍNEZ-JERÓNIMO, F. \& RAMÍREZGRANADOS, R. 1992. Tasa de filtración y cultivo de Moina macrocopa (Crustacea: Cladocera) alimentada con Scenedesmus incrassatulus (Chlorophyceae) y estiércol vacuno digerido. An. Inst. Cienc. Mar Limnol. http://biblioweb.tic.unam.mx/cienciasdelmar/instituto/1992-2/ articulo410.html (último acesso em 30/06/2013).

FREITAS, E.C. \& ROCHA O. 2011. Acute and chronic effects of sodium and potassium on the tropical freshwater cladoceran Pseudosida ramosa. Ecotoxicology 20:88-96. http://dx.doi.org/10.1007/s10646-010-0559-z 
GOULDEN, C.E. 1968. The systematics and evolution of the Moinidae. Trans. Am. Philos. Soc. 58(6):1-101. http://dx.doi.org/10.2307/1006102

HAMMER, Ø., HARPER, D.A.T. \& RYAN, P.D. 2001. PAST: Paleontological Statistics Software Package for Education and Data Analysis. Palaeontol. Electron. 4(1):1-9.

HAMMER, U.T. 1986. Saline Lake Ecosystems of the World. Monographiae Biologicae 59. Dr. W. Junk Publishers, Dordrecht.

HANAZATO, T. \& YASUNO, M. 1984. Growth, reproduction and assimilation of Moina macrocopa fed on Microcystis and/or Chlorella. Jap. J. Ecol. 34(2):195-202.

IANNACONE, J.A. \& DALE, W. 1999. Protocolo de bioensayos ecotoxicológicos para evaluar metales pesados contaminantes de agua dulce con Chironomus calligraphus (Diptera: Chironomidae) y Moina macrocopa (Crustacea: Cladocera), en el río Rímac, Lima, Perú. Rev. Per. Ent. 41:111-120.

IANNACONE, J.A. \& ALVARIÑO, L. 2000. Chironomus calligraphus Goeldi y Moina macrocopa (Sars) como herramientas ecotoxicológicas para la evaluación del lindano y clorpirifos. Bol. Soc. Biol. Concepción (Chile) 71:33-39.

IANNACONE, J.A. \& ALVARIÑO, L. 2002. Evaluación del riesgo ambiental del insecticida CARTAP en bioensayos con tres invertebrados. Agric. Téc. 62(3):366-374.

JOSE DE PAGGI, S., PAGGI, J.C., COLLINS, P., COLLINS, J. \& BERNAL, G. 2008. Water quality and zooplankton composition in a receiving pond of the stormwater runoff from an urban catchment. J. Environ. Biol. 29(5):693-700.

LÖFFLER, H. 1961. Beiträge zur Kenntnis der Inranischen Binnengewsswer". II. Regional-limnologische Studie mit besonderer Berücksichtigung der Crustaceen-Fauna. Int. Revue. ges Hydrobiol. 46:309-406.

LOH, J.O., HOW, C.W., HII, Y.S., KHOO, G., KIAT, H. \& ONG, A. 2009. Fish faeces as a potential food source for cultivating the water flea, Moina macrocopa. JOSTT. 5:5-9.

MAC-QUHAE, C.A., ROMERO, C. \& MORALES, D.A. 2007. Toxicidad aguda del hidróxido de sodio sobre Moina macrocopa (Crustácea, Branquiopoda). Ecotrópicos 20(1):24-30.

MARTÍNEZ, F. \& GUTIÉRREZ, A. 1997. Fecundity, reproduction and growth of Moina macrocopa fed on different algae. Hydrobiología 222:49-59. 1 http://dx.doi.org/10.1007/BF00017499

MARTÍNEZ-TABCHE, L., GÓMEZ-OLIVÁN, L., MARTÍNEZ, M., CASTILLO, C. \& SANTIAGO, A. 2000. Toxicity of nickel in artificial sediment on acetylcholinesterase activity and hemoglobin concentration of the aquatic flea, Moina macrocopa. J. Environ. Hydrol. 8(4):1-10.

NANDINI, S., MAYELI, S.M. \& SARMA, S.S.S. 2004. Effect of stress on the life-table demography of Moina macrocopa. Hydrobiologia 526:245-254. http://dx.doi.org/10.1023/B:HYDR.0000041597.96720.ff

NATIONAL ADVISORY COMMITTEE ON INVASIVE SPECIES. 2010. National strategy on invasive species in Mexico, prevention, control and eradication. http://www.conabio.gob.mx/invasoras/images/e/e4/ Invasive_species_Mexico_dec2010.pdf (último acesso em 30/06/2013).

OKOLODKOV, Y.B., BASTIDA-ZAVALA, R., IBÁÑEZ, A.L., CHAPMAN, J.W., SUÁREZ-MORALES, E., PEDROCHE, F. \& GUTIÉRREZ-
MENDIETA, F.J. 2007. Especies acuáticas no indígenas en México. Cienc. Mar. 11(32):29-67.

PAGGI, J.C. 1997. Moina macrocopa (Straus 1820) Branquiopoda, Anomopoda) in South America: another case of species introduction? Crustaceana 70(8):886-893. http://dx.doi.org/10.1163/156854097X00500

PEREYRA, A., ABIATI, N. \& FERNÁNDEZ, E. 2004. Manual de estadística para proyectos de investigación. Ed. Fac.de Cs Agrarias, Universidad Nacional de Lomas de Zamora.

PONCE DE LEÓN, E. 1998. Evapotranspiración. In El agua en La Pampa (Fundación Chadileuvú). Fondo Editorial Pampeano, Santa Rosa, p.31-42.

RICCIARDI, A. \& RASMUSSEN, J.B. 1999. Extinction rates of North American Freshwater Fauna. Conserv. Biol. 13(5):1220-1222. http:// dx.doi.org/10.1046/j.1523-1739.1999.98380.x

SARMA, S.S.S., NANDINI, S., MORALES-VENTURA, J. DELGADOMARTÍNEZ, I., GONZÁLEZ-VALVERDE, L. 2006. Effects of $\mathrm{NaCl}$ salinity on the population dynamics of freshwater zooplankton (rotifers and cladocerans). Aquat. Ecol. 40:349-360. http://dx.doi.org/10.1007/ s10452-006-9039-1

SMIRNOV, N.N. 1976. Macrothricidae I Moinidae fauni mira. Fauna SSSR. Rakoobraznie 1(3):1-237. (Macrothricidae and Moinidae of the world. In Russian).

SOKAL, R. \& ROHLF, F. 1995. Biometría. Principios y métodos estadísticos en la investigación biológica. Ed. Blume, Barcelona. 832p.

SUHETT, A.L., STEIMBERG, C.E.W., SANTÁNGELO, J.M., BOZELLI, R.L. \& FARJALLA, V.F. 2011. Natural dissolved humic substances increase the lifespan and promote transgenerational resistance to salt stress in the cladoceran Moina macrocopa. Environ. Sci. Pollut. Res. 18(6):1004-1014. http://dx.doi.org/10.1007/s11356-011-0455-y

UNIÓN MUNDIAL PARA LA NATURALEZA - UICN. 1999. Cuarta Reunión del Órgano Subsidiario de Asesoramiento Científico, Técnico y Tecnológico. Especies Invasoras. Recomendaciones. 6 pp. http://ereespecies-invasoras.wikispaces.com/file/view/ UICN+especies+invasoras+Humbolt.pdf(último acesso em 30/06/2013).

VALDIVIA-VILLAR, R.S. 1988. Checklist of freshwater Cladocera from Perú. Amazoniana 10:283-297.

VANJARE, A.I., PADHYE, S.M. \& PAI, K. 2010. Zooplankton from a polluted river, Mula (India), with record of Brachionus rubens (Ehrenberg, 1838) epizoic on Moina macrocopa (Straus, 1820). Opusc. Zool. Budapest 41(1):89-92.

VIGNATTI, A. 2011. Biomasa del zooplancton en lagunas salinas y su relación con la concentración de sales en ausencia de peces. Tesis Doctoral, Universidad Nacional de Río Cuarto, Facultad de Ciencias Físico Químicas y Naturales.

VIGNATTI, A., CABRERA, G. \& ECHANIZ, S. 2012. Changes in the zooplankton and limnological variables of a temporary hypomesosaline wetland of the central region of Argentina during the drying. PanamJAS 7(2):93-106.

WALKER, B. \& STEFFEN, W. 1997. An overview of the implications of global change and manager terrestrial ecosystems. Conserv. Biol. 1(2): http://www.ecologyandsociety.org/vol1/iss2/art2/manuscript.frames.html (último acesso em 30/06/2013)

ZAR, J.H. 1996. Biostatistical analysis. 3. ed. Prentice Hall, New Jersey, 988p. 